\begin{abstract}
Iranica
Abstracta Iranica Revue bibliographique pour le domaine irano-aryen

Volume 32-33 | 2013

Comptes rendus des publications de 2009-2010
\end{abstract}

\title{
U. Weber. Wahrām II., König der Könige von Ērān und Anērān
}

\section{Barbara Kaim}

\section{(2) OpenEdition}

1 Journals

\section{Édition électronique}

URL : http://journals.openedition.org/abstractairanica/40587

DOI : 10.4000/abstractairanica.40587

ISSN : 1961-960X

Éditeur :

CNRS (UMR 7528 Mondes iraniens et indiens), Éditions de l'IFRI

\section{Édition imprimée}

Date de publication : 1 décembre 2013

ISSN : 0240-8910

\section{Référence électronique}

Barbara Kaim, « U. Weber. Wahrām II., König der Könige von Ërān und Anērān », Abstracta Iranica [En

ligne], Volume 32-33 | 2013, document 206, mis en ligne le 01 juillet 2016, consulté le 03 octobre 2020

URL : http://journals.openedition.org/abstractairanica/40587 ; DOI : https://doi.org/10.4000/ abstractairanica.40587

Ce document a été généré automatiquement le 3 octobre 2020.

Tous droits réservés 


\section{U. Weber. Wahrām II., König der Könige von Ērān und Anērān}

\section{Barbara Kaim}

\section{RÉFÉRENCE}

U. Weber. « Wahrām II., König der Könige von Ērān und Anērān ». Iranica Antiqua, 49, 2009, p. 559-643.

1 Très intéressant et utile aperçu des sources écrites et iconographiques concernant le règne de Wahram II.

\section{AUTEURS}

\section{BARBARA KAIM}

Université de Varsovie 